\title{
Beholding the Emerging Biodiversity Agreement through a Looking Glass
}

\author{
What Capacity-Building and Gender Equality Norms Should Be \\ Found There?
}

Ronán Long

\begin{abstract}
Many developing countries do not have adequate scientific capability to benefit from the sustainable development of the ocean or to implement their international legal obligations under the Convention and related instruments. In light of this shortcoming, the chapter seeks to address fundamental questions pertaining to the adoption of new normative obligations in the ввNJ Agreement on education and training in marine scientific research (MSR), including the codification of gender-sensitive norms. The chapter concludes that the Agreement has the potential to be a game-changer on capacity-building if it results in the following: the establishment of a robust institutional setting for decision-making supported by the proposed clearing-house mechanism; codifies the requirements of undertaking a regular 'needs assessment'; provides a solid legal plinth for gender equality and the empowerment of women scientists; and most importantly of all establishes a mandatory and sustainable funding stream for capacity-building. Furthermore, the negotiators should bring about transformational change in the law of the sea by addressing these issues directly at the final session of the intergovernmental conference.
\end{abstract}

\section{Keywords}

intergovernmental conference - capacity-building - biodiversity - gender equality inequalities - language - law of the sea - marine scientific research - United Nations Convention on the Law of the Sea - women 
The world is fighting a global pandemic associated with the relentless spread of the severe acute respiratory syndrome coronavirus $2 .{ }^{1}$ The multiple causes of the pandemic are manifest with compelling and longstanding evidence pointing towards a confluence of factors including the rapid growth of urbanisation, air travel and the unsustainable exploitation of the natural environment, among others. $^{2}$ As we witness the fragility of human existence and the dire consequences of uninformed encroachment into nature, it is perhaps pertinent to recall how Lewis Carroll used a looking glass as a literary device in one of his celebrated novels to show an irrational world characterised by strange behaviour and unexpected outcomes. ${ }^{3}$ Similarly, if we hold a mirror to the world that exists around us today then it also evident that the natural and societal environments are not as they should be or could be, mainly due again to a whole range of anthropogenic phenomena that are leading to the mass extinction of biodiversity including catastrophic losses of species and entire ecosystems in the world's largest repository, the ocean environment. ${ }^{4}$ This escalating state of affairs is also putting the collective wellbeing of humanity and future generations at risk. ${ }^{5}$

The transnational responses of governments to the loss of biodiversity appear fragmented with just a handful of multilateral processes underway to safeguard community interests in the protection and preservation of the global environment. ${ }^{6}$ Crucially however they include protracted efforts at the United Nations (UN) to negotiate a new legal instrument under the United Nations Convention on the Law of the Sea (the Convention) on the conservation and sustainable use of marine biodiversity beyond national jurisdiction (BвNJ). ${ }^{7}$

1 Editorial, 'COVID-19: learning from experience' 395(10229) The Lancet, March 28, 2020.

2 N. Madhav, B. Oppenheim, M. Gallivan, P. Mulembakani, E. Rubin, and N. Wolfe, 'Pandemics: Risks, Impacts, and Mitigation' in D. Jamison, H. Gelband, S. Horton, et al., Disease Control Priorities: Improving Health and Reducing Poverty 3rd Ed., (Washington DC: World Bank, 2017), Chapter 17.

3 L. Carroll, Through the Looking-Glass, and What Alice Found There, $5^{\text {th Ed (Oxford Compan- }}$ ion to English Literature: 1986).

4 UN Environment (2019). Global Environment Outlook - GE O-6: Healthy Planet, Healthy People. Nairobi. DO I 10.1017/9781108627146.

5 Ibid.

6 See conservation related efforts pursuant to the following: UngA 'Transforming Our World: The 2030 Agenda for Sustainable Development' UN Doc A/REs/70/1 (21 October 2015); Paris Agreement 2015 (into force 4 November 2016) FCCC/CP/2015/10/Add.1.

7 UN, Revised draft text of an agreement under the United Nations Convention on the Law of the Sea on the conservation and sustainable use of marine biological diversity of areas beyond national jurisdiction, A/CONF.232/2O2O/3, 18 November 2019. For commentary on the 
At one level, the latter negotiations represent a rare chink of light on the relatively pedantic world of international law-making as it applies to the ocean. On another level, they also present a once in a generation opportunity for transformational change in the law of the sea through the codification of innovative provisions in the so-called 'BBNJ Agreement' (hereinafter the Agreement) on capacity-building and marine scientific research (MSR), including the codification of gender-sensitive norms for the first time in a law of the sea treaty.

In framing the case supporting the inclusion of new normative obligations in the Agreement on such issues, perhaps it is best to start out by noting that state practice over the past four decades demonstrates that the provisions on MSR set forth in the Convention have served the interests of developed countries in the international community very well, ${ }^{8}$ by-and-large it must be said, through the facilitation of scientific inquiry into ocean processes and resources that is multi-faceted and in many instances transnational in substance, scope and geographical application. ${ }^{9}$ Despite the vital role that science plays in the management of ocean activities, it is also increasingly apparent that many developing countries, especially Small Island Developing States (SIDS) and

в ВNJ processes up the time of writing; see inter alia: D Freestone (ed), Conserving Biodiversity in Areas beyond National Jurisdiction (Brill/Nijhoff 2019). On the preparatory phase of the negotiations, see: R. Long, J. Brincat, 'Negotiating a New Biodiversity Instrument at the United Nations: A European Union Perspective on the Preparatory Phase' in M. Nordquist, J. N. Moore, R Long, Cooperation and Engagement in the South China Sea And Asia Pacific Region (Leiden/Boston: Brill/Nijhoff, 2019) 443-468; R Long and M Rodríguez-Chaves, 'Anatomy of a New International Instrument for Biodiversity beyond National Jurisdiction: First Impressions of the Preparatory Process' (2015) 6 Environment Liability 214.

8 See inter alia: S. Rosenne, A.Yankov, M. Nordquist et al., United Nations Convention on the Law of the Sea 1982: A Commentary (Dordrecht/Boston/Lancaster, Martinus Nijhoff Publishers, 1991) Vol. IV, 429-657; K. Bartnstein, S. Hamamaton in A. Proelss (ed), United Nations Convention on the Law of the Sea: A Commentary (Beck, Hart and Nomos 2017) 1605-1761; M. Gorina-Ysern, Marine Scientific Research (Transnational Publishers, Inc., Ardsley, 2003); F.H. Wegelein, Marine Scientific Research, The Operation and Status of Research Vessels and Other Platforms in International Law (Martinus Nijhoff Publishers, Leiden/Boston, 2005); United Nations, Guide for the Implementation of the Relevant Provisions of the UN Convention on the Law of the Sea (United Nations, Office for Ocean Affairs and the Law of the Sea, New York, 1991); A. Soons, Marine Scientific Research and the Law of the Sea (Kluwer Law and Taxation Publishers, Deventer, 1982.

9 Ibid. 
Least Developing Countries (LDCs), do not have adequate scientific capability to benefit from the sustainable development of the ocean or to implement their international legal obligations under the Convention and related instruments. ${ }^{10}$ Indeed without enhanced access to scientific knowledge and skills, it is difficult to see how these countries can reap the benefits that are to be derived from sustainable uses of biodiversity or more pressingly through taking appropriate action to redress the existentialist dangers posed to their very existence by environmental damage and marine resource depletion. ${ }^{11}$ Furthermore, these failings are compounded by the barriers that impede women scientists from participating in MSR and from equal representation at all levels in public and private spheres concerned with the conservation and sustainable use of biodiversity both within and beyond national jurisdiction. Again, this failing is most acute in relation to women scientists working in the globalsouth and in some of the world's poorest countries.

In light of the aforementioned shortcomings, the paper touches upon three fundamental questions, namely: (1) Is the law of the sea adequate to the task of capacity-building for BвNJ under existing international agreements; (2) What considerations are driving the adoption of new normative obligations in the Agreement on education and training in MSR, including the codification of gender-sensitive norms?, and following on from this; (3) Do the intergovernmental negotiations at the UN present an opportunity for a paradigm shift that will enhance the scientific capabilities of developing States, particularly those of SIDS and the LDCs?

Gender Rights: Research and Advocacy at the World Maritime University

At the outset, it ought to be noted that the discussion in this chapter is informed by the success of the capacity-building mission of the World Maritime University (WMU) over the past 37 years including the delivery of specialised postgraduate offerings in maritime and ocean affairs to students from developing

10 United Nations General Assembly, 'Report of the Secretary-General on oceans and the law of the sea'. UN Doc A/65/69 (2010); UNGA Preparatory process of the United Nations Conference to Support the Implementation of Sustainable Development Goal 14: Conserve and sustainably use the oceans, seas and marine resources for sustainable development: especially paras $323-325$ at 88 . Ibid. 
countries. ${ }^{12}$ In addition, the chapter is shaped by the work of the University on the empowerment of women in the maritime sector. ${ }^{13}$ This work extends to a specialist research and capacity-building programme underway at the WMUSasakawa Global Ocean Institute (GOI) on the empowerment of women scientists for the UN Decade of Ocean Science for Sustainable Development (20212030). ${ }^{14}$ Supported by the Department of Fisheries and Ocean of Canada, the latter programme has its origin in Canadian $\mathrm{G}_{7}$ initiatives aimed at tackling gender inequality at a global level. ${ }^{15}$ In launching the research programme and by way of highlighting some of the inequalities that needed to be tackled, the Hydrographer General of Canada, Dr. Genvieve Béchard, drew attention to the poor gender balance in the organisations of the member states that contribute to the work of the International Hydrographic Organization ( $\mathrm{IHO}$ ), with only five national hydrographic organisations led by women and none in developing countries. ${ }^{16}$

In order to explore how best to break down barriers that impede women in scientific careers, the first strand of the research programme explores the role of gender equality and the empowerment of women in the conduct of ocean science and the delivery of advisory services by the International Council for the Exploration of the Sea (ICES). The ICES is made-up of a community in excess of 6,ooo marine scientists working in public and private settings including

12 R. Long, 'The World Maritime University - Sasakawa Global Ocean Institute: A New Institute in a Unique University' 50(2019) Ocean Development and International Law 225-234.

13 M. Kitada, 'Advancing 'Good Practices' that Promote Gender Equality in the Maritime Sector' in I. Papanicolopulu (ed.) Gender and the Law of the Sea (Leiden/Boston: Brill/ Nijhoff, 2019) 302-317.

14 Sponsored by the Department of Fisheries and Oceans Canada. See: press release: Launch of Recruitment for Ph.D. Scholarship and Post-Doctoral Fellowship Programme Empowering Women for the United Nations Decade of Ocean Science for Sustainable Development, 31 May 2019. Available at: https://wmu.se/news/launch-recruitment-phdscholarship-and-post-doctoral-fellowship-programme-empowering-women.

15 Canadian were subsequently picked-up by the French G7 Presidency in 2019 and led to the establishment of G7 Gender Equality Advisory Council. See Biarritz Partnership, Recommendations of the Gender Equality Advisory Council for advancing gender equality and the empowerment of girls and women and Call to Action. Available at: https:// www.elysee.fr/admin/upload/default/ooo1/o5/cfb1e2ba2b9aaogc166ofib6df2cabbc815eecc2.pdf.

16 Australia, Canada, Croatia, Denmark and Norway. See Report Third Conference on the Empowerment of Women in the Maritime Community, available at: https://safety4sea.com/wp-content/uploads/2019/o9/WMU-Third-WMU-International-WomensConference-Empowering-Women-in-maritime-community-2019_o9.pdf. 
universities. ${ }^{17}$ This element also entails a study of gender equality in the ocean and freshwater science communities of Kenya, as well as women empowerments efforts undertaken within the framework of the Nairobi Convention for the Protection, Management and Development of the Marine and Coastal Environment of the Eastern African Region. ${ }^{18}$ This is complemented by a second tangential thread of inquiry that entails an analysis of gender equality in the regulatory and ocean governance systems organisations that depend upon and deliver ocean science, with a particular focus on: the Food and Agriculture Organization (FAO), the International Seabed Authority (ISA), the Intergovernmental Oceanographic Commission of UNESCO (IOC-UNESCO); as well as non-governmental organizations involved in the BBNJ negotiation process at the UN. ${ }^{19}$ One of the programme outputs is the design of an action plan on the empowerment of women within ocean science organisations and science dependent ocean governance systems that can be applied globally throughout the UN Decade of Ocean Science. ${ }^{20}$

In parallel with the aforementioned programme, researchers at the GOI are engaging in extra-mural advocacy initiatives at intergovernmental conferences and technical workshops hosted by UN system bodies including most notably at the penultimate session of the intergovernmental conference (IGC) on the conservation and sustainable use of BBNJ. ${ }^{21}$ These advocacy opportunities

17 ICES has 20 member nations: Belgium, Canada, Denmark, Estonia, Finland, France, Germany, Iceland, Ireland, Latvia, Lithuania, The Netherlands, Norway, Poland, Portugal, Russian Federation, Spain, Sweden, United Kingdom, and the United States. Affiliate institutes with observer status are located in the following: Australia, Chile, Greece, Peru, and South Africa. Worldwide Fund for Nature and Birdlife International have formal observer status at meetings of ICES.

18 Nairobi Convention for the Protection, Management and Development of the Marine and Coastal Environment of the Eastern African Region, 21 June 1985, into force 30 May 1996, 91 RGDiP 1122, (1993) UNEP Register 228, amended 31 March 2010 (not in force); 1985 Protocol Concerning Protected Areas and Wild Fauna and Flora in the East African Region, into force 30 May 1996, 985 IELMT 47.

19 See: https://wmu.se/docs/phd-scholarship-and-post-doctoral-fellowship-programmeempowering-women-united-nations-decade.

$20 \quad$ Ibid.

21 The initiatives also include, inter alia: the inaugural meeting of the Commonwealth Action Group on Ocean Observation, Ottawa, Canada, 30 May 2019, the Ioc General Assembly Meeting 2019, Side Event hosted by the Government of Canada on Empowering Women through the UN Decade of Ocean Science for Sustainable Development, Paris, France, 27 June 2019; Governing Science at Sea: The Legal Framework for Marine Scientific Research, Korea Institute Ocean science and Technology (кIOST), Berkeley Law, Law of the Sea Institute (LOSI), Busan, Republic of Korea, 16-17 July 2019; Regional Workshop, 
have been used to draw attention to the importance of including gender sensitive norms in the Agreement and extended to co-hosting a side event on this subject with Ireland and Palau at the third session of the IGC in September 2019. ${ }^{22}$ Surprisingly, this was the first side event on capacity-building and gender-sensitive norms since the intergovernmental dialogue on the conservation and sustainable use of biodiversity commenced over 15 years ago. ${ }^{23}$ The event was well attended by negotiators and included a keynote address by the President of the World Maritime University, along with contributions from: the Secretary-General of the International Seabed Authority; the gender focal point scientist of the IOC-UNESCO; the Director of Legal and External Affairs at the International Maritime Organization: as well as commentaries from senior diplomatic representatives of the Pacific sIDs, the Caribbean sids and Indonesia. ${ }^{24}$ Many participants voiced their concerns about the importance of moving from words to action in the international law-making process through the codification of new normative obligations on capacity-building, marine scientific research and the empowerment of women in the Agreement. The case and opportunity for doing so are reviewed below.

\section{$4 \quad$ Language Matters}

Building capacity or developing capacity in MSR: which is it? The answer to this question is not self-evident and in delving forth, it is therefore necessary to drill down on the meaning of some key terms used in this paper,

North Atlantic Ocean, UN Decade of Ocean Science for Sustainable Development (20212030), Halifax, Canada, 7-10 January 2020; the ISA International Workshop on Capacity Development, Resources and Needs Assessment, Kingston, Jamaica, 10-12 February 2020.

22 See: https://wmu.se/news/capacity-building-gender-empowerment-and-bbnj-agreement.

23 One can compare and contrast the progressive evolution of gender equality and women's empowerment initiatives at a range of international bodies since the 1980 s including at IUCN, see: Gender Equality and Women's Empowerment Policy: Mainstreaming Genderresponsiveness within the IUCN Programme of Work Approved by the IUCN Council at its 95th Meeting, IUCN C/95/8, October 2018, available at: https://www.iucn.org/sites/dev/ files/annex_9_to_c_95_8_iucn_gender_equality_and_womens_empowerment_policy.pdf. On women and international treaty law, see, H. Charlesworth, 'Women' in S. Chesterman, D. Malone, and S. Villalpando (Ed.) Oxford Handbook of UN Treaties (Oxford: OuP, 2019) 249-265.

24 R. Long and Z. Sun (eds.), Workshop Report: Biodiversity Beyond National Jurisdiction: Towards the Development of a Balanced, Effective and Universal International Agreement (Malmö: World Maritime University, 2020) at 76. 
specifically: 'capacity-building', 'capacity-development', 'marine scientific research' and 'gender equality'.

Starting out with the penultimate term first, the Convention for well documented reasons does not attempt to define what constitutes MSR, or any other form of scientific research for that matter. ${ }^{25}$ The Convention nonetheless has extensive provisions on MSR as well as references to 'survey activities', 'prospecting' and 'exploration and exploitation' in relation to seabed mining. ${ }^{26}$ Moreover, despite science going to very heart of a dispute between Australia, New Zealand and Japan, the International Court of Justice did not offer a general definition of 'scientific research', or find it necessary to do so in rendering its judgment in the Antarctic Whaling case. ${ }^{27}$ From a law of the sea viewpoint, the meaning of MSR thus remains open textured and can be viewed as a general term to describe activities undertaken in the marine environment that expand scientific knowledge of the ocean and its processes. ${ }^{28}$

Similarly to the absence of clarity on what constitutes MSR, the terms 'capacity-building' and 'capacity-development' are not terms of art under the Convention or related instruments. ${ }^{29}$ The architects of the Convention did however use a formulation of words to describe measures that are aimed at providing technical assistance to developing States in a range of provisions addressing living resources, the Area, the marine environment, and marine scientific research. ${ }^{30}$ Thus, for example, in the context of the provisions on the development and transfer of marine science and technology, Article 266 (2) refers to States, particularly developing States, which may 'need and request technical assistance in regard to the exploration, exploitation, conservation and management of marine resources, the protection and preservation of the marine environment, MSR and other activities in the marine environment compatible

25 R. Long, 'Regulating Marine Scientific Research in the European Union: It Takes more than Two to Tango' in M. Nordquist, J. N. Moore, F. Soons, and H. Kim (eds.) The Law Of The Sea Convention: U.S. Accession And Globalisation (Leiden/Boston, Martinus Nijhoff Publishers, 2012) 427-4 at 440-491.

26 Parts II, III, XI, XII, Annex III, as well as in the 1994 Agreement relating to the Implementation of Part XI, along with the mining code.

27 The Whaling in the Antarctic (Australia V. Japan: New Zealand intervening) 2014 I.C.J. General List No. 148 (March 31) at paras. 73-86.

28 A. Roach, R. Smith, Excessive Maritime Claims, 3ed. (Leiden/Boston: Martinus Nijhoff, 2012) 414 .

29 Article 266, Convention. See K. Bartnstein, 'Development and Transfer of Marine Technology' in Proelss (ed.), United Nations Convention on the Law of the Sea: A Commentary (Beck, Hart and Nomos 2017) 1765 .

Articles 62(4)(j), 144, 2020, 203, 244, Convention. 
with the Convention', ${ }^{31}$ The objective of technical assistance in this instance is the acceleration of the 'social and economic development of States', ${ }^{2}$ a goal reflective of the debate on the establishment of a New Economic Order at the Third United Nations Conference (UNCLOS III). ${ }^{33}$

Outside of the domain of the law of the sea treaties, the use of the terms 'capacity-building' and 'capacity development' are all pervasive in UN documents, reports and instruments, particularly those emanating from the UN General Assembly. ${ }^{34}$ The precise meaning of the terms is frequently difficult to discern, particularly so when they are used interchangeably in the specialist literature. That aside, the two terms are considered to have different connotations in different contexts. ${ }^{35}$ The UnDP 'Practice Note on Capacity Development' for instance draws a number of distinctions regarding the two terms in that it provides that: 'capacity development commonly refers to the process of creating and building capacities and their (subsequent) use, management and retention. This process is driven from the inside and starts from existing national capacity assets. ${ }^{36}$ The Note goes on to state that 'capacity building' refers on the other hand to a 'process that supports only the initial stages of building or creating capacities and alludes to an assumption that there are no existing capacities to start from. ${ }^{37}$

At what point does the initial capacity-building activities transform into the longer-term capacity-development? In answering this question, it is illustrative to note that the International Seabed Authority (ISA) considers its initial training activities after the coming into force of the 1994 Implementation Agreement as capacity-building initiatives. ${ }^{38}$ Similar to the approach

31 Article 266(2), Convention.

32 Article 266(2), Convention.

33 See Recital 5, Preamble, Convention, as well as commentary by K. Bartnstein, in A Proelss (ed.), note 8,1765 .

34 For example, there are 13 references to capacity-building in UNGA resolution adopted 25 September 2015: A/RES/7O/1 - Transforming our world: the 2030 Agenda for Sustainable Development including a specific call in Goal 17.9 for enhanced "international support for implementing effective and targeted capacity-building in developing countries to support national plans to implement all the SDG s, including through North-South, SouthSouth and triangular cooperation."

35 UNDP, UNDP Practice Note: Capacity Development (New York, UNDP, 2008) at 5 . Available at: https://www.undp.org/content/undp/en/home/librarypage/capacity-building/capacitydevelopment-practice-note.html.

36 Ibid.

37 Ibid.

38 Secretariat of the ISA, Review of Capacity-Building Programmes and Initiatives Implemented by the ISA, Version 1.2, 5 February 2020, at 7 . 
advocated by the UNDP Practice Note on the subject, it considers the term capacity-development as a more accurate description of future training programmes and initiatives that will be undertaken by the Authority. ${ }^{39}$ Indeed, the strategic plan of the ISA uses the term capacity-development to describe the technical training mission and mandate of the Authority for the period $2019-2023 .{ }^{40}$ The trend of using the term 'capacity development' is also evident in the IOC-UNESCO publications on the Decade of Ocean Science, which aims to build global scientific capacity to achieve the objectives of the 2030 Agenda. ${ }^{41}$

In contrast to the approach adopted by IOC-UNESCO, the draft text of the Agreement does not refer to capacity development but addresses comprehensively 'capacity-building and the transfer of marine technology' in the same set of provisions (Part V, Articles 42-45), thereby presenting them as complementary activities that go hand-in-hand.$^{42}$ Although these provisions are highly prescriptive and reviewed further below, suffice to note here that the draft text does not define expressly the meaning of the term 'capacity-building', nor does it allude to the possibility of the latter evolving into 'capacity-development' at some future point during the course of implementation of the Agreement. ${ }^{43}$

39 Ibid.

40 ISA, Decision of the Assembly of the International Seabed Authority relating to the strategic plan of the Authority for the period 2019-2023ISBA/24/A/10, 27 July 2018. Available at: https://ran-s3.s3.amazonaws.com/isa.org.jm/s3fs-public/files/documents/ isba24_a1o-en.pdf.

41 IOC-Unesco Draft Implementation Plan, Decade of Ocean Science for Sustainable Development (Paris: IOC-Unesco, 18 March 2020) 17-20. Available at: file:///Users/rl/ Downloads/Implementation_Plan_Zero_Draft_March_2020\%2O(1).pdf.

The United States is a longstanding and well-versed opponent to the transfer of technology provisions in Parts XIII and XIV of the Convention. The wisdom of this conjunctive approach linking capacity-building with the transfer of technology may yet prove to be a bridge-too-far in attracting US support for the putative Agreement. See Jon M. Van Dyke, David L. Teichmann (1984) 'Transfer of seabed mining technology: A stumbling block to U.S. ratification of the law of the sea convention?', Ocean Development and International Law, 13:4, 427-455, DOI: 10.108o/oogo8328409545736.

43 The group of Core Latin American States (CLAMS) submitted a definition in a proposal on capacity building on the 20 February 2020 , which defines the term as meaning: 'any activity intended to enable or improve academic, professional and technical training; the exchange of knowledge and skills; access to physical infrastructure; institutional strengthening; communication between relevant actors; the exchange of scientific information, technological development and innovation; and raising awareness through public information and basic knowledge about marine biodiversity in areas outside of national jurisdiction'. This proposed definition draws from the concepts included in the IOC Capacity Development Strategy 2015-2021, available at: https://www.un.org/bbnj/ sites/www.un.org.bbnj/files/textual_proposals_compilation_-_28_feb_2020.pdf. 
Indeed, a practical perspective would suggest that a combination of the two would be more appropriate to the task at hand, that is to say initial and ongoing capacity-building and capacity-development, which may be a more beneficial avenue to improve the effectiveness of the Agreement in the fullness of time.

Finally, although the discussion is primarily concerned about inequalities among men and women pursuing marine scientific careers, it ought to be noted that the term 'gender' refers to a range of identities, which may not correspond to the binary characterisation of a person as male or female. ${ }^{44}$ For the purpose of the chapter, gender equality is understood to mean that a person's rights and opportunities is not dependent on this characterisation but is about realising full human potential, human rights and social justice. According to UN Women:

Gender Equality means that the rights, responsibilities and opportunities of individuals will not depend on whether they are born male or female. Equality does not mean "the same as" - promotion of gender equality does not mean than women and men will become the same. Equality between women and men has both a quantitative and a qualitative aspect. The quantitative aspect refers to the desire to achieve equitable representation of women - increasing balance and parity, while the qualitative aspect refers to achieving equitable influence on establishing development priorities and outcomes for women and men. Equality involves ensuring that the perceptions, interests, needs and priorities of women and men (which can be very different because of the differing roles and responsibilities of women and men) will be given equal weight in planning and decision-making. ${ }^{45}$

In essence, gender equality and the empowerment of women scientists necessitates engaging with all of humankind to meet the challenges encountered in ocean science and the law of the sea on the conservation and sustainable use of ввNJ. ${ }^{46}$

44 J. Archer, and B. Lloyd, Sex and Gender, 2ed., (Cambridge: Cambridge University Press, 2002).

45 UN Women, Important Concepts Underlying Gender Mainstreaming (New York: UN, 2001). Available at: https://www.un.org/womenwatch/osagi/pdf/factsheet2.pdf.

46 G. Goettsche-Wanli, 'Gender and the Law of the Sea: a Global Perspective' in I. Papanicolopulu (ed.) Gender and the Law of the Sea (Leiden/Boston: Brill/Nijhoff, 2019) $25-82$. 
Bearing in mind that the Agreement is an implementation instrument under the Convention, one can ask if existing provisions in the parent treaty are adequate to the task of capacity-building for BBNJ? There are over two dozen references in the Convention to providing technical assistance to developing States in various forms. ${ }^{47}$ The Convention does not however identify which States qualify for such assistance, although various categories of States have been discussed during the course of the BBNJ processes including least-developed countries, landlocked developing countries, geographically disadvantaged States, SIDS, coastal African States and developing middle-income countries. ${ }^{48}$

Briefly stated, the technical assistance articles in the Convention can be grouped into four sets of the provisions addressing: seabed mining; ${ }^{49}$ the protection and preservation of the marine environment; ${ }^{50}$ marine scientific research ${ }^{51}$ and development and transfer of marine technology. ${ }^{52}$ Many of the provisions are hortatory in nature and characterised by inherent weaknesses and ambiguities regarding the obligations that they impose on States Parties and other entities. For instance, apart from acknowledging that MSR is a freedom of the high seas, ${ }^{53}$ there is little guidance on how research, prospecting and exploring of the International Seabed Area (the Area) are to distinguished in practice, bearing in mind that each of these activities are subject to different requirements under Annex III of the Convention, the 1994 Implementation Agreement, and the mining code. ${ }^{54}$ That said, Annex III is unique in the law of the sea and has a rare strength in that it sets down an express obligation on mining contractors to provide practical programmes for the training of the personnel of the ISA and developing States. ${ }^{55}$ Moreover, States Parties are compelled as a general rule under the 1994 Implementation Agreement to promote international technical and scientific cooperation with regard to activities in the Area. ${ }^{56}$ This obligation is further elaborated upon in the

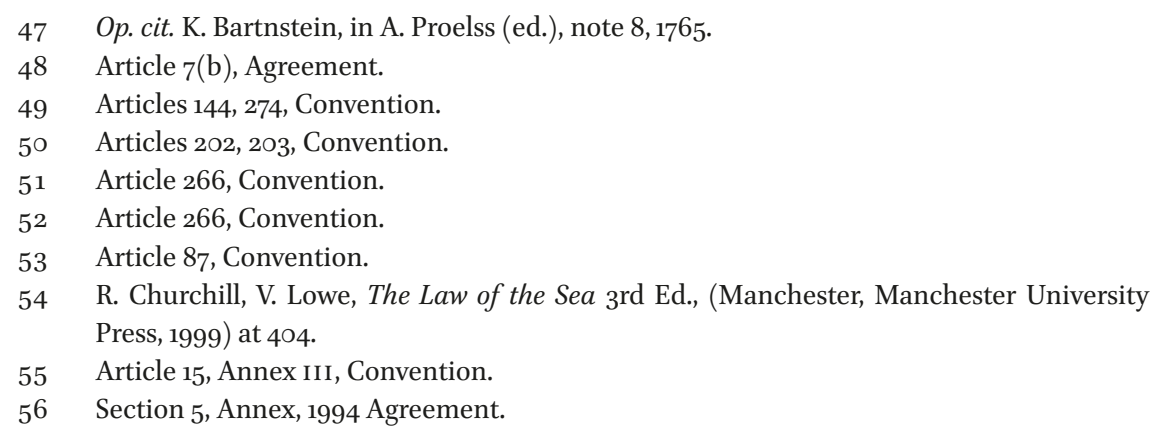


prospecting and exploration code for seabed mining, which provide that the training programmes must be drawn up and paid for by the contractor, working in cooperation with the Authority and the sponsoring State or States. ${ }^{57}$ The legally-binding nature of the training obligations was also highlighted in the first Advisory Opinion handed down by the Seabed Disputes Chamber of ITLOS, which noted that the legal responsibilities of States Parties with respect to activities in the Area included ensuring that developing States received the necessary assistance including training. ${ }^{58}$

A number of general points can be made about the other provisions in the Convention on technical assistance. First, the provisions on the protection and preservation of the marine environment in Part XII are less compelling than those on seabed mining and very much couched in the language of promoting technical assistance programmes to aid developing States. ${ }^{59}$ Crucially, they do not provide a solid legal basis for mandatory and legally binding obligations in relation to the delivery of capacity building resources or expertise to developing States. That said, the provisions in Part XII are premised on assistance having been provided directly or through the good offices of international organizations and extend to training, equipment, the development of facilities for research, monitoring, educational and other programmes. ${ }^{60}$ In addition, appropriate assistance must be provided for pollution incidents and for the preparation of environmental assessments. In relation to pollution incidents, developing States are to be granted preference by international organizations in relation to financial support and technical assistance. ${ }^{61}$

Second, on a broader geographical scale, technical training programmes and initiatives for developing States on a voluntary basis are implicit in the provisions on living resources, as well as the rights of land-locked States and geographically disadvantaged States. ${ }^{62}$

57 See, for example, Regulation 3.i(a), Regulation 29, Section 8 of Annex IV, Regulations on Prospecting and Exploration for Cobalt-rich Ferromanganese Crusts in the Area, IS BA/18/ A/11, 22 October 2012.

58 Responsibilities and Obligations of States Sponsoring Persons and Entities with Respect to Activities in the Area (Advisory Opinion) [2011] It Los Rep 10 (Seabed Mining Advisory Opinion), para. 163 .

59 Article 202, Convention.

6o Article 202(a), Convention.

61 Article 202(a), Convention.

62 Article 70, 72(2), Convention. See, K. Bartnstein, S. Hamamaton in A. Proelss (ed.), United Nations Convention on the Law of the Sea: A Commentary (Beck, Hart and Nomos 2017) 16o5-1761. 
Third, the negotiators at UNCLOS III were aware of the importance of capacity-building for MSR and adopted a resolution on the development of national marine science, technology and ocean service infrastructures, which called for the promotion of programmes of scientific, educational, technical and other assistance to developing States for the protection and preservation of the marine environment and the prevention, reduction and control of marine pollution. ${ }^{63}$ Indeed, the success of the provisions on MSR (Part XIII) and the transfer of marine technology (Part XIV) is almost entirely contingent upon the voluntary implementation of the resolution in practice by developed States Parties. Viewed in this light, the Agreement represents an opportunity to redress the shortcomings of the Convention in providing viable mechanisms for capacity building.

Fourth, the provisions on technical assistance and training in the Convention are complemented by other schemes in international law and ocean science. ${ }^{64}$ They include a broad suite of initiatives implemented by UNEP in furtherance of its Regional Seas Conventions and Action Plans, which apply to ABNJ of the North East Atlantic, Pacific, Mediterranean and Southern Ocean (Antarctic) and are undertaken by Regional Coordination Units and Regional Activity Centres. Likewise, regional capacity-building is a cornerstone of fisheries management training programmes with several tailored initiatives delivered by the five tuna RFMOs and the eight deep-sea RFMOs. The International Maritime Organization has its own technical assistance programme valued at about 14 million USD per annum, which is funded from a variety of sources including the Global Environment Facility, the European Union and the Norwegian Agency for Development and Cooperation. ${ }^{65}$ Specialised post-graduate education for students from developing countries is delivered by the World Maritime University in Sweden and by the IMo International Maritime Law Institute in Malta. ${ }^{66}$

63 Appended to the Final Act of the Conference as Annex vi.

64 There is an excellent summary of complementary initiatives in UN Doc A/65/69 (2010), op. cit. note 10. Also, Biliana Cicin-Sain (et al.), 'Policy Brief on Capacity Development as a Key Aspect of a New International Agreement on Marine Biodiversity Beyond National Jurisdiction (ввNJ)', August 2018. Available at: http://www.fao.org/fileadmin/user upload/common_oceans/docs/policy-brief-on-bbnj-capacity-development-aug-2018.pdf.

65 IMO, Annual report on the technical cooperation activities implemented under the Integrated Technical Cooperation Programme during 2018, TC 69/3(a), 18 April 2019. Available at: http://www.imo.org/en/OurWork/TechnicalCooperation/ITCP/Documents/ TC\%2069-3(a)\%20-\%2oAnnual\%2oReport\%2ofor\%202018.pdf. 
All-in all, capacity-building under the Convention and related instruments falls well short of what is required to meet the needs of developing States in relation to the scientific aspects of decision-making on the conservation and sustainable use of ввNJ. ${ }^{67}$ With the benefit of hindsight, it is also evident that the piecemeal approach and the lack of a strong thematic cross-cutting strand on technical assistance has undermined the effectiveness of the Convention as a capacity-building instrument over the past four decades. ${ }^{68}$ Moreover, the MSR provisions in the Convention are dated in so far as they are primarily concerned with ship-based research and and refecting the era when they were negotiated say little if anything about the application of satellite technologies, autonomous sensors, as well as the use of artificial intelligence tools to the task of ocean observation and the sampling of biodiversity for scientific and other purposes. ${ }^{69}$ Many of the latter tools do not require ocean scientists to spend long stints at sea and offer pathways to careers that are more amenable to scientists with family responsibilities. ${ }^{70}$

Outside of the domain of the seabed mining provisions, the absence of mandatory funding mechanisms and dedicated financial resources must also be viewed as major failings that completely undermine the practical utility of the capacity-building obligations that arise under the Convention. ${ }^{71}$ These shortcomings are compounded by the absence of a legal basis for intergovernmental coordination on capacity-building pertaining to marine research including genetic research, along with undertaking the science associated with the establishment of MPAs and the conduct of EIA s. ${ }^{72}$ Furthermore, although 25 years have passed since the coming into force of the Convention, no comprehensive assessment has been undertaken at a global level of the MSR needs of developing States. ${ }^{73}$ This requirement is ever more pressing with the First

67 UN Doc A/65/69 (2010), op. cit. note 10. Also, Biliana Cicin-Sain (et al.) op. cit. note 64.

68 Ibid.

69 See inter alia: R. Long, "A European Law Perspective: Science, Technology and New Challenges to Ocean Law" in H. Scheiber, J. Kraska (eds.), Science, Technology, And New Challenges To Modern Ocean Law, (Leiden/Boston, Martinus Nijhoff, 2015) 65-123; J. Kraska, Y. Kil-Park (ed.), Emerging Technology and the Law of the Sea (Cambridge: Cambridge University Press, forthcoming).

70 See section 6.4 infra.

71 See section 7.4 infra.

72 UN Doc A/65/69 (2010), op. cit. note 10, paras 161-181. The report in footnote 212 mentions two initiatives undertaken by the Imo, the 'Global Programme on Integration of Women in the Maritime Sector', and the establishment of regional associations for women in the maritime sector.

Ibid., paras 295, 321 and 325 . 
Global Integrated Marine Assessment (the Assessment) drawing attention to major gaps in the MSR capacity of developing States, particularly in relation to the human skills and knowledge that can be applied in decisions concerning the conservation and sustainable use of вв NJ. ${ }^{74}$ Specifically, the Assessment identified needs in taxonomy, genetics, as well as bio-physical and chemical research on the ocean environment, along with a number of related fields and skills. ${ }^{75}$ The Assessment is largely silent on the gender bias in ocean science but makes detailed reference to the importance of gender considerations in fisheries and aquaculture industries. ${ }^{76}$ Without quantifying the scale of the improvement, the Assessment does however allude to an ever-increasing number of women in technical, scientific and managerial careers in the latter two sectors. ${ }^{77}$

The weaknesses in the law of the sea on capacity-building can be partly explained by the negotiation period of the Convention itself, which is a treaty child of the 1970s. An obvious lacuna stems from the absence of express normative obligations on gender balance and the empowerment of women. ${ }^{78}$ The supposedly gender-neutral norms set out in the Convention have been questioned on the basis that they perpetuate inequalities in the law of the sea institutions, particularly the International Tribunal on the Law of the Sea and the Commission on the Limits of the Continental Shelf, as well as in capacitybuilding programmes and more generally in relation to careers in the maritime domain, including within the sphere of MSR. ${ }^{79}$ Clearly, the law of the sea as currently constituted is not adequate to the task of building-capacity in MSR or to advancing gender sensitive norms for the purpose of implementing the objectives of the Agreement.

74 United Nations, The First Integrated Marine Assessment (Cambridge University Press 2016), Chapter 53, 923-933. See discussion of clearing-house mechanism infra.

75 Ibid., 924.

76 Ibid. There are for instance 32 references to gender in the chapter on the social and economic aspects of sea-based food and fisheries, see especially pp 34-35. Available at: https://www.cambridge.org/core/services/aop-cambridge-core/content/view/ CoFF1CAEC 3 D80892309BFBEC6A69364D/9781108186148c15_p229-238_CBO.pdf/ social_and_economic_aspects_of_seabased_food_and_fisheries.pdf.

77 Ibid.

78 R. Long (unpublished paper), 'Gender and the Law of the Sea Convention: Is it All about Buoys?' delivered at an international conference, Exploring the human element of the oceans: the gender implications of the law of the sea, School of Law, University of MilanoBicocca, 25 May 2017.

I. Papanicolopulu (ed.) Gender and the Law of the Sea (Leiden/Boston: Brill/Nijhoff, 2019). 
The scientific and policy considerations underpinning the law of the sea are continuously changing in response to new uses and pressures on the ocean environment, along with technological and economic developments, with some of the greatest changes occurring since the conclusion of the Convention in 1982. Four of the dynamics that are at play and that should have a bearing on the outcome of the BBNJ negotiations are briefly enumerated below.

\subsection{Reinforcing a Crucial Nexus: Science, Law and Capacity-Building}

Our knowledge of the ocean is extremely limited, particularly so in relation to BвNJ. ${ }^{80}$ The capacity building provisions of the Agreement must therefore aim to strengthen the vital nexus that links the scientific and legal dimensions of the law of the sea. The importance of reinforcing this link cannot be understated as it is central to ensuring the conservation and sustainable use of the ocean, as well as to the stable and peaceful public order of maritime affairs. At a very practical level, many decisions in ocean governance need to be based on the best available science and empirical evidence derived from pure and applied MSR. ${ }^{81}$ Within various ocean governance settings, scientists commonly bear the heavy burden of providing advice to decision-makers relating to the design and implementation of sector specific policies that apply both within and beyond national jurisdiction. ${ }^{82}$ They also partake in and inform the work undertaken by intergovernmental organizations and regional seas and fisheries management bodies, including their efforts to manage living resources sustainably, to map the oceans for navigation and other purposes, to address the adverse impacts of climate change, and to ensure food security in the LDC s. ${ }^{83}$ This work is frequently supported by the expert services of specialist regional

80 United Nations, The First Integrated Marine Assessment (Cambridge University Press 2016) 8, 936. Also see, T. Webb et al., 'Biodiversity's big wet secret: The global distribution of marine biological records reveals chronic under-exploration of the deep pelagic ocean' (2010) 5 PLoS One, e10223.

81 Y. Tanaka, The International Law of the Sea, 3 Ed., (Cambridge: Cambridge University Press, 2019) 432-45o. See also, in this volume, L. Mayer and J.A. Roach, 'The Quest to Completely Map the World's Oceans in Support of Understanding Marine Biodiversity and the Regulatory Barriers we Have Created'.

82 On the science policy nexus, see for example, UNGA Res $72 / 72$, paras $54-58$. Also, D.F. Boesch, 'The role of science in ocean governance', 31 (1999) Ecological Economics 189-198.

83 For instance, the International Maritime Organization, the Food and Agriculture Organization (FAO), the International Seabed Authority (ISA), the Intergovernmental Oceanographic Commission of UNESCO (IOC-UNESCO), among many others. 
scientific bodies, such as the International Council for the Exploration of the Sea (ICES) and the North Pacific Marine Science Organization (PICES), ${ }^{84}$ which are mandated with collecting and exchanging scientific information, along with providing scientific advice concerning the planning and managing of offshore activities including activities that impinges upon the environmental status of вBNJ. ${ }^{85}$

The conservation and sustainable use of biodiversity under the Agreement must therefore be viewed first and foremost as a scientific challenge that needs to be resolved on the basis of the data and knowledge derived from MSR. Without appropriate scientific training and access to deep science capabilities, scientists from developing countries including women scientists will be curtailed in contributing to the institutional arrangements established by the Agreement, especially the proposed Scientific and Technical Body. ${ }^{86}$ Furthermore, as pointed out previously, the capacity gap in MSR between developed countries and developing countries will continue to broaden with notable regional disparities regarding the resources and know-how available to scientists in the global-south. ${ }^{87}$ Indeed, unless the link between science and law are strengthened and operationalised for developing States, it is difficult to see how they will derive tangible benefits from the Agreement. This explains why capacitybuilding is viewed by many negotiators attending the BBNJ intergovernmental conference as a cross-thematic strand of the negotiations, closely linked to the functioning of the clearing-house mechanism, as well as a key enabler for the successful implementation of the three substantive elements of the draft treaty pertaining to MGRS and benefit sharing, ABMTs including MPAs, and EIA S. ${ }^{88}$ Looking to the future, the results of MSR will be crucial to improved understanding of the functioning of high seas ecosystems and the successful

84 Convention for The International Council for the Exploration of the Sea (ICES), 652 UNTS 237; Convention for a North Pacific Marine Science Organization (PICES) 207 UNTS 189, Amendment May 20, 1987.

85 Statement of Anne Christine Brusendorff on behalf of International Council for the Exploration of the Sea (ICES) at IGC 3. Available at: https://www.ices.dk/news-andevents/Documents/Press\%2oRoom/Areas\%2oBeyond\%2oNational\%2oJuristiction.pdf.

86 C. Salpin, V. Onwuasoanya, M. Bourrel, and A. Swaddling, (2016). 'Marine scientific research in Pacific Small Island Developing States', (2016) 95 Marine Policy 363-371.

$87 \quad$ Op. cit. note 8.

88 UN, Statement by the President at the closing of the third session, and the report of the Informal working group on capacity-building and the transfer of marine technology A/CONF.232/2019/10*, 13 September 2019, 17/23-19-23, especially the discussion on the clearing-house mechanism, paras 13-14. 
implementation of the Agreement. ${ }^{89}$ The draft treaty thus presents an exceptional opportunity to strengthen the international framework for deep-ocean science and to enhance the functional cooperation between States, as well as public and private bodies, including cooperation on the implementation of capacity-building programmes to meet the special needs of the LDCs and siDs. The framework for transnational cooperation will be further bolstered by capacity development activities undertaken pursuant to the UN Decade of Ocean Science and to implement obligations arising under the 2030 Agenda. ${ }^{90}$

\subsection{Mitigating Environmental Risk and Enhancing Ocean Resilience}

At the heart of the Agreement are procedural and spatial management tools embedded in the provisions on EIA and ABMTs, which can be applied in mitigating environmental risk and to enhancing ocean resilience. They are also linked to capacity-building provisions in the Agreement that can help close the skills-gap in developing countries that are needed to design effective strategies that build resilience in ecological systems that provide essential services, as well as in addressing the factors that degrade biodiversity, both within and beyond national jurisdiction. ${ }^{91}$ The scale of the capacity-building tasks is daunting because anthropogenic impacts on biodiversity are placing new demands on the MSR resources and scientific needs of both developed and developing States. ${ }^{92}$ At the same time, there is a preponderance of evidence showing funding for ocean science remains at best 'modest' in general terms but is totally inadequate in meeting the needs of developing States. ${ }^{93}$ This failing is compounded by the regional disparity in the geographical distribution, educational opportunities and resources that are available to ocean scientists in the LDC s and SIDs, particularly so when compared to developed countries. ${ }^{94}$ The shortage in resources is most acute in relation to deep-ocean research vessels and the specialist equipment that is needed to evaluate environmental risk and to implement strategies at national and regional levels that

89 A. Rogers, U. Sumaila, S. Hussain, and C. Baulcomb, The High Seas and Us: Understanding the Value of High Seas Ecosystems (Oxford: Global Ocean Commission, 2014).

9o IOC-Unesco Draft Implementation Plan, Decade of Ocean Science for Sustainable Development (Paris: IOC-UNESCO, 18 March 2020) at 19.

91 United Nations, The First Integrated Marine Assessment, op. cit. note 74 and UN Doc. A/70/ 112 at $13 / 6$ o.

92 Ibid., and IOC-UnESCO, Global Science Report 2017.

93 IOC-UnESCO, Global Science Report 2017, at 27.

94 Ibid., at 28-31. 
build ecological resilience. ${ }^{95}$ Moreover, there are several other imperatives that need to be taken into consideration with several international reports pointing out that policy responses and regulatory action are not progressing sufficiently well to arrest the widespread decline of biodiversity in both the terrestrial and ocean environments. ${ }^{96}$ The 'Intergovernmental Science-Policy Platform on Biodiversity and Ecosystem Services Report 2019' ranks capacitybuilding and cross-sector cooperation as two of the principal interventions to redress the alarming deterioration of nature. ${ }^{97} \mathrm{~A}$ similar finding is evident in the IPCC 'Special Report on the Ocean and Cryosphere in a Changing Climate' (SROCC), which states with high confidence that 'changes in the ocean have impacted marine ecosystems and ecosystem services with regionally diverse outcomes, challenging their governance.' ${ }^{8}$ The SROcc points out that 'people with the highest exposure and vulnerability are often those with lowest capacity to respond'. ${ }^{99}$ For this reason, the report recommends investment in education and capacity building at various levels and scales to reduce risk and enhance resilience. ${ }^{100}$ Women in particular are disproportionately affected by environmental risks and according to the European Institute for Gender Equality (EIGE) are not taken into account in many decisions concerning recovery and adaptation strategies. ${ }^{101}$

The inclusion of appropriate norms on capacity-building and gender equality in the Agreement can help redress these shortcomings by ensuring ocean science is transformative in orientation and by establishing mechanisms to improve the uptake and use of science by future States Parities, including LDC s and and sids. By doing so, the Agreement will contribute to one of the core objectives of the Decade of Ocean Science, which is to 'distribute [scientific] capacity across the globe, across generations, and across genders and thus

95 Ibid., on the nationality and availability of research vessels for deep ocean science, at 66-73.

96 Intergovernmental Science-Policy Platform on Biodiversity and Ecosystem Services, The Global Assessment Report on Biodiversity and Ecosystem Services (Bonn: IPBEs Report 2019), available at: https://ipbes.net/global-assessment.

97 IPBES Report 2019, 'Summary for Policy Makers', D2 Five main interventions at 17. Available at: https://ipbes.net/sites/default/files/2020-02/ipbes_global_assessment_ report_summary_for_policymakers_en.pdf.

98 IPCC, 2019: Summary for Policymakers. In: IPCC Special Report on the Ocean and Cryosphere in a Changing Climate, at SPM-17, available at: https://report.ipcc.ch/srocc/ pdf/SROCC_FinalDraft_FullReport.pdf.

99 Ibid., at SPM-34.

100 Ibid., at 40-41.

101 EIGE, 'Gender in Environment and Climate Change', (Luxembourg: EIGE, 2016) available at: file:///Users/rl/Downloads/ti_pubpdf_mho2169o1enn_pdfweb_201701241440o8.pdf. 
reverse asymmetry in knowledge, skills and access to technology'102 Ultimately, this approach will facilitate the participation and education of scientists from LDC s and sIDs in the design and implementation of decisions that mitigate environmental risk and build resilience of ввNJ.

\subsection{Implementing Sustainability and Blue Economic Objectives}

The wider sustainability and blue growth agendas are increasingly informing all aspects of the law of the sea. ${ }^{103}$ The 2030 Agenda is universal and speaks to the needs of both developing and developed countries across a broad spectrum of thematic areas that are of critical importance to wellbeing of humankind and the future of the planet. ${ }^{104}$ The Agreement must therefore be viewed through the prism of the 2030 Agenda and how it can contribute to the attainments of its 17 indivisible and interlinked SDG S. ${ }^{105}$ In particular, the MSR, capacity-building and gender provisions therein have the potential to make a substantial contribution to the realisation of the SDG S on learning opportunities (SDG 4), gender equality (SDG 5), sustainable economic growth (SDG 8), climate action (Goal 13) and oceans (SDG 14). They will also add significant weight to the attainment of Target 14A of SDG 14, which sets down an obligation to increase scientific knowledge, develop research capacity and the transfer of marine technology. ${ }^{106}$ The Agreement when it comes into force will be the very embodiment of Target 14.C, which aims to enhance the conservation and sustainable use of oceans and their resources by implementing international law as reflected in the Convention. ${ }^{107}$ In doing so, it will bolster international efforts on the attainment of the SDG s by using science, education and gender empowerment as drivers for sustainable development, contributing at

102 IOC-Unesco 'Draft Implementation Plan', Decade of Ocean Science for Sustainable Development (Paris: IOC-UNESCO, 18 March 2020) at 17.

103 M. Nordquist, J. N. Moore, R. Long (eds.), The Marine Environment and UN Sustainable Development Goal 14: Life Below Water (Leiden/Boston, Brill/Nijhoff, 2018).

104 M. Robinson in F. Dodds, D. Donoghue and J. Roesch, Negotiating the Sustainable Development Goals: A Transformational Agenda for an Insecure World (London/ New York: Routledge, 2017) at XV, cited by R. Long, M. Chaves-Rodriguez, "Bridging the Water, Oceans and Climate Change Goals under the 2030 Agenda for Sustainable Development" in M. Nordquist, J. N. Moore, R. Long (eds.) The Marine Environment And UN Sustainable Development Goal 14 (Leiden/Boston, Brill/Nijhoff, 2018) 83-110.

105 UN Resolution 70/1. Transforming our world: the 2030 Agenda for Sustainable Development, A/RES/70/1, 21 October 2015. See inter alia: M. Nordquist, J. N. Moore, R. Long (eds.) The Marine Environment and United Nations Sustainable Development Goal 14: Life Below Water (Leiden/Boston, Brill/Nijhoff, 2018).

106 UN Resolution 70/1, at 24/35.

107 Ibid. 
the same time to the realisation of the strategic objectives of the Decade of Ocean Science. ${ }^{108}$ According to IOC-UNESCO, the projected gains from the delivery of these objectives in the context of the SDGs are manifold and extend in theory to the following:

..the ocean has the potential to supply up to six times more food that it does today (SDG2 - zero hunger). New technologies in renewable energy or carbon storage could increase the capacity of the ocean to mitigate the worst effects of climate change (SDG7 - affordable and clean energy; SDG13 - climate action). New knowledge and tools for coastal naturebased solutions could increase the adaptive capacity of hundreds of millions of the most vulnerable people $\left(\mathrm{SDG}_{3}\right.$ - good health and wellbeing; SDG1o - reduced inequalities)..$^{109}$

Instructively, political leaders in developing countries are increasingly aware of the significance of education and gender empowerment, ranking them as top priorities under the 2030 Agenda. ${ }^{110}$ This ranking is unsurprising and accords very much with the finding of a World Bank report that investment in educational systems not only enhances employment but also pays a substantial dividend by fostering institutional capacity, social cohesion and human wellbeing, especially in SIDs. ${ }^{111}$ Indeed according to the World Bank, the absence of capacity, skills and financial resources impede SID s and LDC s from pursuing a low-carbon and resource-efficient path to economic growth and development designed to enhance livelihoods for the poor, create employment opportunities, and reduce poverty'.12 Following on from this, the inclusion of capacity

108 IOC-Unesco Revised Roadmap Appendix 2: Paris 8 June 2018, p 35.

109 Ibid., at 2-3.

110 Despite international efforts to raise awareness of the symbiosis that ought to exist between ocean science and sustainable development, the attainment of Goal 14 related targets is not a political priority in many developing countries, according to one major survey of leaders in low- and middle-income countries undertaken by at a social science laboratory at William and Mary University. See, AidData's 2017 'Listening to Leaders Survey'. Nearly 3,50o leaders working in 22 different areas of development policy shared their views via AidData's 2017 Survey. Available at: https:/www.aiddata.org/data/ the-2017-listening-to-leaders-survey-aggregate-dataset.

111 United Nations Department of Economic and Social Affairs, 'The Potential of the Blue Economy: Increasing Long-term Benefits of the Sustainable Use of Marine Resources for Small Island Developing States and Coastal Least Developed Countries' (Washington: World Bank, 2017).

112 Ibid., at ix. 
building in MSR and gender norms in the Agreement should not be viewed solely as objectives in themselves but if formulated skilfully and constructively, can also make a vital contribution to the implementation of a broad swathe of SDGs, as well as generating the right conditions for sustainable economic growth of countries dependent on the ocean environment and on the sustainable use of marine resources. ${ }^{113}$

\subsection{Mainstreaming Gender Equality and Empowering Women}

The UN Secretary-General identifies gender equality and the empowerment of women as one of greatest human rights challenges faced by the world today. ${ }^{114}$ Human rights consideration are also increasingly pervasive in the law of the sea with the International Tribunal for the Law of the Sea stating unequivocally that 'considerations of humanity must apply in the law of the sea, as they apply in other areas of international law'.115 In practice, however, the law of the sea is male law to its very core. ${ }^{116}$ There is nothing unusual in this as international law has been slow to engage with gendered dynamics outside of the field of human rights and international criminal law. ${ }^{117}$ Hence, an important aspect of the Agreement is its potential to advance equality between women and men in international law of the sea. This in turn will bring this body of law into line with a discrete and delicate strand of UN treaty law on the elimination of gender discrimination more generally through the medium of authoritative prescription. ${ }^{118}$

The reasons for pursuing a gendered approach are many including marshalling of the widest pool possible of scientific and technical experts to undertake the many tasks associated with the conservation and sustainable use of

113 On the potential of MGRs to contribute to blue economic development, see J. Collins, Report of the Workshop "Marine genetic resources in areas beyond national jurisdiction: bridging policy, law, science and research and development" (Brussels: European commission, 2019). Available at: https://op.europa.eu/en/publication-detail/-/publication/aca8co5f-c875-11e9-9do1-o1aa75ed71a1/language-en/format-PDF/source-104428893.

114 UN Secretary-General António Guterres, Remarks, 8 February 2020. Available at: https:// www.un.org/sg/en/content/sg/speeches/2020-02-08/remarks-high-level-meetinggender-equality-and-womens-empowerment.

115 ITLos, MV Saiga (No. 2)(Saint Vincent And The Grenadines V. Guinea) case, (1999) 38 ILM 1355 at para. 155 .

116 I. Papanicolopulu (ed.) Gender and the Law of the Sea (Leiden/Boston: Brill/Nijhoff, 2019).

117 C. MacKinnion, 'Creating International Law: Gender as Leading Edge', (2013) 36(1) Harvard Journal of Law and Gender 105-122.

118 H. Charlesworth, 'Women' in S. Chesterman, D. Malone, and S. Villalpando (eds.) Oxford Handbook of UN Treaties (Oxford: OUP, 2019) 249-265, especially 264. 
biodiversity. ${ }^{119}$ Education, training and capacity-building are vital pathways to improving gender equality and the empowerment of women scientists under the Agreement. There is considerable amount of work to be done in this regard with UNDP estimating that the number of women graduates in science, engineering and technology and mathematics is less than 15 per cent of the total number of third-level university graduates in most countries. ${ }^{120}$ Furthermore, there is longstanding evidence that 'women are still under-represented in many research fields, generally receive lower salaries, are less likely to have full-time contracts and have fewer opportunities to gain influential positions than their male colleagues'.121

The case supporting the inclusion of specific provisions that empower women scientists in the Agreement is a compelling one because women are underrepresented in ocean science, particularly in the specialist fields related to ocean technology and engineering. ${ }^{122}$ The data is incomplete but indicates that the total number of women scientists amounted to 38 per cent of the total cohort of ocean scientists in $2013 .{ }^{123}$ One should exercise considerable care with this figure, as there is significant disparity within ocean regions such as the North Pacific Ocean, ${ }^{124}$ as well as in countries such as Mauritania where women comprise four per cent of the total cohort of ocean scientists. ${ }^{125}$ Furthermore, the IOC Report notes that there were fewer women in senior professional roles or management positions, a finding that is common in other scientific disciplines. ${ }^{126}$ Overall, the findings presented by the Global Ocean Science Report reflect the well-established patterns of bias that limit women's choices, opportunities and active participation in science careers more commonly. ${ }^{127}$

119 See statement of Ioc-unesco, See Ioc-unesco, Ad Hoc Report of the Intergovernmental Oceanographic Commission (IOC) of Unesco to BBNJ PrepCom4, at 8 and 29. Available at: https://www.un.org/Depts/los/biodiversityworkinggroup/ IOCreportforBBNJPrepCom-FINAL.PDF.

120 Cited in UNDP, 2020 Human Development Perspectives. Tackling Social Norms: A game changer for gender inequalities (New York: UNDP, 2020).

121 S. Palermo, E. Giuffra, V. Arzenton, M. Bucchi 'Gender and science', 2008;9(6) EMBO Rep. 494-495. Available at https://www.embopress.org/doi/pdf/10.1038/embor.20o8.82.

122 IOC-Unesco, Global Ocean Science Report, 2017. Available at http://unesco.org/gosr.

123 Ibid. The relatively high cohort of women scientists, reported by IOC at 38 per cent, appears to be derived from data on the number of women attending international conferences and workshops and not the total number of women participating in MSR more generally.

124 Ibid.

125 Ibid.

126 Ibid.

127 EIGE, Gender in Environment and Climate Change, op. cit. note 101. 
Against this background, there is thus a corresponding need to improve the representation of women scientists in the various categories of ocean science, as well as in the geographical distribution of scientists across the world including most notably in the LDC s and sIDS. This will entail the adoption and strengthening of policies and laws that actively further the empowerment of women and girls in ocean science. A timely step in the right direction, can be undertaken under the mantle of the Agreement, if its provisions ensure the full and equal participation of women in all capacity-building initiatives, education and employment opportunities, as well as all decision-making processes pertaining to the conservation and sustainable use of biodiversity. The reasons for doing so are self-evident in so far as gender equality and the empowerment of women will bring in fresh perspectives and thereby increase the innovative capacity of ocean science. Furthermore, according to UNESCO, gender equality in science in general, encourages the search for new solutions and expands the scope of research and development. A similar approach under the Agreement that actively promotes gender balance will help attain many SDGs under the 2030 Agenda and at the same time ensure that gender equality and the empowerment of women scientists are realisable objectives of the UN Decade of Ocean Science for Sustainable Development. ${ }^{128}$

Capacity-building and technology transfer is one for the four substantive topics in the Agreement package that was agreed at the United Nations in 2011 and has since been subject to extensive deliberations at the Preparatory Committee (2015-2017) ${ }^{129}$ as well as at three sessions of the Intergovernmental Conference (2018-2019). ${ }^{130}$ As mentioned above, the inclusion of comprehensive and enfranchising provisions on capacity-building are a prerequisite to a successful outcome to the negotiations. ${ }^{131} \mathrm{~A}$ valid question therefore is how far the Agreement will codify new normative obligations on capacity-building, MSR and the empowerment of women. The answer to the question is very much contingent upon the provisions that the plenipotentiaries agree upon during the final session(s) of the IGC. Although it is not possible to draw any definitive conclusions while the negotiations are ongoing, the contours of what can be

\footnotetext{
128 IOC-UNESCO, Decade of Ocean Science Draft Implementation Plan, at 17-18.

129 Op. cit. note 7.

130 Ibid.

131 See statements by PSIDS, CARICOM and OASIS at IGC 3 .
} 
achieved are evident from a brief perusal of the various options canvassed in Part V of the draft text prepared by the President for the negotiators at IGC 4, along with additional elements addressed in Part I on use of terms, Part VI on the clearing-house mechanism, Part VII on financial resources, and Part viII on Implementation and Compliance. ${ }^{132}$ At the time of writing four general points can be made about the draft provisions.

\subsection{Narrow Objectives and a Dearth of Ambition}

The capacity-building objectives are relatively narrow and focused primarily on the twin-goals of aiding future States Parties in implementing their obligations under the Agreement and in providing them with the wherewithal to benefit from activities thereunder. ${ }^{133}$ Other objectives relate to increasing and sharing knowledge on the conservation and sustainable use of biodiversity. ${ }^{134}$ One of the most contentious aspects relate to the building and sharing of expertise on the collection, access and use of MGRS in situ, ex situ and digital sequence information, which will require innovative technical solutions if they are to be realised in practice. ${ }^{135}$ The objectives also aim to empower developing States to undertake the tasks associated with the area-based management tools and environmental impact assessment and strategic environmental assessment, thereby linking the capacity-building provisions with the three other substantive parts of the Agreement. There was general recognition at previous sessions of the intergovernmental conference of the importance of the cross-thematic and relatively wide scope of the capacity-building provisions. ${ }^{136}$ There is no reference however in the draft text to the wider sustainability or climate change related goals of capacity-building, which illustrates a dearth of ambition on the part of the negotiators and a disconnect with global environmental, sustainability and climate agendas. Similarly, gender equality and the empowerment of women scientists are not presented as goals in themselves or as central tenets of the capacity-building or other provisions in the Agreement. Furthermore, the need for improving such capacity is all the more evident when it is considered that the implementation of the Agreement

\footnotetext{
132 Op. cit. note 7 .

133 Article 42(a) and (b), Agreement.

134 Article 42(d), Agreement.

135 Article 42(f)(i)-(iv), Agreement. In relation to the innovative solutions that are required, see chapter in this volume by Marcel Jaspers, 'Mare Geneticum - Building Blocks Towards a Pragmatic Solution for ABS in ABNJ'.

136 Article $42(\mathrm{f})(\mathrm{v})(\mathrm{vi})$, Agreement. See Annex to the statement of the President of the Conference, Third Session, 19-3o August 2019, UN A/CONF.232/2019/5, available at: https:// undocs.org/a/conf.232/2019/5.
} 
will place a heavy responsibility on flag States, many of whom are Least Developed Countries and do not have the means or know-how to discharge their new found obligations in relation to deep ocean biodiversity.

\subsection{Enhanced Cooperation, New Institutional Settings, and a Clearing- House Mechanism}

Similar to other law of the sea instruments pertaining to the protection and preservation of the marine environment and in line with the jurisprudence of international courts and tribunals, ${ }^{137}$ there is considerable emphasis on international cooperation as the very foundation of the obligations placed on future States Parties to the Agreement. ${ }^{138}$ A novel aspect of the draft text is that it provides a legal basis for partnerships with the private sector, civil society and the holders of traditional knowledge. ${ }^{139}$ The monitoring and review provisions are focused on reviewing the needs and gaps in capacity-building, along with measuring performance and making recommendations on how developing countries can fulfil their obligations under the Agreement. ${ }^{140}$ The process is intended to be inclusive and one of the options canvassed by the draft text is a voluntary reporting requirement for States Parties. ${ }^{141}$ A major development relates to the establishment of a new institutional setting for international decision-making on conservation and sustainable use of biodiversity including a possible role for the COP in establishing a subsidiary-body for capacitybuilding and a clearing-house mechanism. ${ }^{142}$ One of the options envisaged is that the latter will operate as an open-access digital platform for the sharing of information and benefits, along with matching capacity-building needs with respect to each of the substantive parts of the Agreement. ${ }^{143}$ The institutional provisions extend to the establishment of a Scientific and Technical Body/Network mandated with functions set out in the Agreement. ${ }^{144}$

137 Article 197, Convention; mox Plant (Ireland v. United Kingdom) Provisional Measures, Order of 3 December 2001, ITLOS Reports 2001, para. 82; 'Case concerning Land Reclamation by Singapore in and around the Straits of Johor' (Malaysia v. Singapore), Provisional Measures, Order of 8 October 2003, ITLOS Reports; 2003, para. 92; Request for an Advisory Opinion Submitted by the Sub-Regional Fisheries Commission (SRFC), Advisory Opinion of 2 April 2015, ITLOS Reports 2015, para. 140.

138 Articles 2,6, 43, Agreement.

139 Article 43(2), Agreement.

140 Article 47, Agreement.

141 Article 47(5), Agreement.

142 Articles 48, 49 and 51, Agreement.

143 Article 51, Agreement.

144 Article 49, Agreement. 


\subsection{Participatory, Cross-Cutting and Gender Responsive}

The issue of gender equality has arisen in the в вNJ negotiation almost by default if not somewhat surreptitiously. More specifically, promoting the role and participation of women was raised by the President of the Preparatory Committee in a non-paper to delegations on the elements of the draft text of the Agreement and identified as one principle and approach that ought to guide capacity-building and transfer of marine technology. ${ }^{145}$ Although this option was not subsequently presented in the report of the Preparatory Committee to the United Nations General Assembly, ${ }^{146}$ it was addressed by the intergovernmental conference at the third session and crucially there are two references to gender in the provisions on capacity-building (Part v) and in the institutional arrangements (Part VI) in the draft text prepared by the President for negotiation at the fourth and final session of the conference. ${ }^{147}$

From the perspective of providing a legal plinth for the training and education of women scientists, the first reference requires capacity-building to be 'participatory, cross-cutting and gender responsive', as well as meeting the needs and priorities of developing States. ${ }^{148}$ Two of the options put forward is that the needs of States Parties may be assessed on the basis of selfassessment or facilitated through a process established by the Conference of the Parties. ${ }^{149}$ Various types of capacity-building are enumerated in the draft text, as well as in Annex II, with the option of a role for the COP in developing the draft list further. ${ }^{150}$ There are also provisions on the periodic monitoring and review of capacity-building. ${ }^{151}$ The second reference to gender relates to the composition of the proposed Scientific and Technical Body and the need to reflect multidisciplinary expertise, gender balance and equitable geographical representation. ${ }^{152}$

Despite the absence of ambition alluded to previously, both references to gender if adopted will represent nonetheless remarkable milestones in the

\footnotetext{
145 The non-paper provided a reference document to assist delegations in their consideration of the issues addressed by the Preparatory Committee. Available at: https://www.un.org/ Depts/los/biodiversity/prepcom_files/Chairs_streamlined_non-paper_to_delegations. pdf.

146 UN Doc. A/AC.287/2017/PC.4/2, 17 July 2017.

147 Article 44(3) and 49(2), Agreement.

148 Article 44(3), Agreement.

149 Article 44(4), Agreement.

150 Article 46, Agreement.

$15^{1}$ Article 47, Agreement.

152 Article 49(2), Agreement. Reference is also made in the draft provision to expertise in relevant traditional knowledge of indigenous peoples and local communities.
} 
progressive development of the law of the sea so far as they acknowledge the importance of gender norms as essential elements in both capacity-building and in the composition of the institutional bodies established by the Agreement. The references do however fall well short of acknowledging gender equality as a fundamental human right or indeed the important role that the empowerment of women can play in achieving human capability, as well as in implementing the SDG s. ${ }^{153}$ This shortcoming could for instance be redressed by making reference to gender equality and the empowerment of women scientists in cross-cutting provisions on principles and approaches that inform all other aspects of the Agreement, ${ }^{154}$ thereby providing a solid legal plinth for the future implementation of gender equality objectives into concrete action and policy decisions. Similarly, a strong case can be made for the inclusion in Annex II of specific types of targeted gender training including education on gender mainstreaming for the appropriate science and governance bodies involved in the conservation and sustainable use of ввNJ. There is little doubt that the needs assessment and periodic review provisions have the potential to close longstanding lacunae highlighted in various science reports including by IOC-Unesco in the Global Marine Science Report. ${ }^{155}$ However, there was no agreement at the third session of the intergovernmental conference as to whether the monitoring and review should be voluntary or mandatory, ${ }^{156}$ or indeed should such processes extend to the review of the gender empowerment performance of the various programmes and initiatives undertaken pursuant to the new Agreement. This could prove to be crucial because the response of many developing States to the advancement of gender norms by the Agreement may well be shaped in many instances by socio-economic and cultural considerations. ${ }^{157}$

\subsection{Financial Resources}

Although capacity-building is an essential element of the Agreement, the options set out in the text leave open a number of important issues regarding the modalities for doing so including whether they should be on a mandatory or voluntary basis. ${ }^{158}$ This goes to the very crux of addressing a fundamental

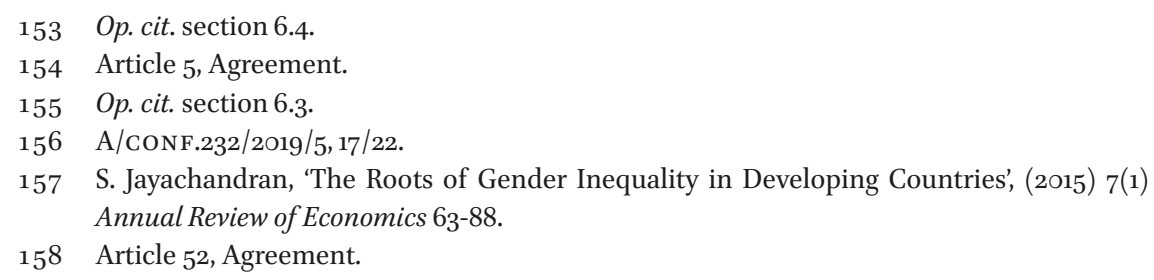


weakness in the Convention, as highlighted previously. The Agreement does however table a range of funding options on capacity-building and again canvases both voluntary and mandatory options including public-private partnerships for supporting the institutions and also to assist developing States in the implementation of the Agreement. ${ }^{159}$ Similar to the Convention, the draft text envisages that developing States parties shall be granted preference in the allocation of funds and technical assistance by international organizations. ${ }^{160}$ Some of the options is the establishment of a voluntary trust fund for the purpose of funding participation of developing country participants in bodies under the agreement, ${ }^{161}$ as well as a special fund to be used for a capacity-building project and to assist developing States Parties in among other matters with the implementation of the Agreement. ${ }^{162}$ The Global Environment Facility and the Green Climate Fund, along with payments tied to access and use of MG R S are also mentioned as possible funding mechanisms. ${ }^{163}$ Pointedly, delegations attending the third session expressed divergent views on the establishment of a special fund and on the role of a future Conference of the Parties in the allocation of funding. ${ }^{164}$ As perhaps expected, there were strong calls from the developing countries at the session for mandatory funding for capacity building, which can be contrasted with the less enamoured views on mandatory funding mechanisms espoused by the delegations representing developed countries including the European Union. There was no discussion of possible pathways to engage with private sector and investment communities by linking for instance the finance provisions in the Agreement with new normative developments such as the UN's 'Principles of Responsible Investment' or the EU's 'Sustainable Blue Economy Finance Principles.'165 Indeed, it is difficult to see how the Agreement will effectively bolster sustainability or growth if it lacks business practicality and appropriate funding mechanisms, especially for capacity-building.

\footnotetext{
159 Article 52(2), Agreement.

160 Article 52(3), Agreement.

161 Article 52(4), Agreement.

162 Article 52(5), Agreement.

163 Article 52(5) bis(e), Agreement.

164 UNGA, Statement by the President of the conference at the closing of the third session, UN doc. A/CONF.232/2019/10*, 13 September 2019.

165 See: https://ec.europa.eu/maritimeaffairs/sites/maritimeaffairs/files/2018-o3-o8-befppress-release_en.pdf.
} 
The answers to the first two questions posed at the start of this paper are relatively easy. That is to say the Convention and related instruments are not adequate to the task of capacity-building to ensure the conservation and sustainable use of B BNJ. ${ }^{166}$ Moreover, there is a multiplicity of considerations driving the codification of new normative obligations in the Agreement on education and training in MSR including gender sensitive norms. ${ }^{167}$ Key considerations are the need to strengthen the capacity and pool of scientists in developing States available to do science and to make informed decisions on the conservation and the sustainable use of BBNJ, as well as the pressing imperatives of creating regulatory and institutional mechanisms for greater integration and coordination of MSR. ${ }^{168}$ Apart from the future Agreement, the policy and regulatory frameworks for doing so include the 2030 Agenda, the Decade for Ocean Science, the Global Ocean Assessment, the Paris Agreement, among many others instruments and processes.

Following on from this, a far more difficult question relates to the intergovernmental negotiations at the United Nations and whether it will result in a paradigm shift that enhances the scientific capabilities of developing States, particularly those of SIDS and the LDCS. The answer is not clear because it often appears at the ввNJ negotiations over the past 15 years that there are always equally strong but diametrically opposing points of view about everything including the putative provisions in the Agreement on capacity-building. Notably, there is no underlying provision in the Agreement concerning the application of capacity-building as an engine for ensuring more equitable uses of the ocean, or pointing towards why mutual benefit exists and can be derived by various ocean users, or how best to regulate modern technologies and especially those used by the public and private sectors. There appears however to be considerable consensus among the negotiators that the challenges faced in managing the conservation and sustainable use of biodiversity can only be tackled by undertaking and applying the results of MSR. There is also general agreement that the science and public policy contexts for capacity-building has changed and is changing, with a large number of delegations supporting a fundamental shift from the voluntary and piecemeal approach to more robust and mandatory provisions on capacity-building in the Agreement. ${ }^{169}$

\footnotetext{
166 Op. cit. section 5 supra.

167 Op. cit. Section 6 supra.

168 K. Kraabel, 'Institutional arrangements in a ввNJ treaty: Implications for Arctic marine science', Marine Policy, available online 9 January 2020.

169 Op. cit. section 6 supra.
} 
As the international community approaches the end of the ввNJ negotiations it is tempting to paraphrase Greta Thunberg advice to global leaders in relation to human induced climate change that in order to solve a crisis, one needs to treat it as a crisis. ${ }^{170}$ Similarly, the BBNJ negotiators can respond to the crisis in deep-ocean biodiversity by adopting and ensuring the entry into force of an effective legal instrument as soon as possible. The capacity development provisions therein will be essential to ensuring its universal acceptance by future States Parties, particularly those from developing countries. Moreover, many involved in the negotiations are acutely aware that the Agreement has the potential to be a game-changer on capacity-building if it results in the following: establishes a robust institutional setting for decision-making supported by the proposed clearing-house mechanism; codifies the requirements of undertaking a regular 'needs assessment'; provides a solid legal plinth for gender equality and the empowerment of women scientists; and most importantly of all establishes a mandatory and sustainable funding stream for capacity-building. ${ }^{171}$ By doing so, the Agreement will also reflect four closely inter-related normative themes, namely: the obligation placed on States and others to cooperate; the concept of interdependence, that is to say that the strong should help the weak; and the principles of conservation and sustainable use of biodiversity. ${ }^{172}$ Time is undoubtedly of the essence and there is no reason to wait. The plenipotentiaries should seize the opportunity at IGC 4 to bring about transformative change in the law of the sea on capacity-building, MSR and gender equality.

The author wishes to acknowledge comments from the following: S. Buckingham, C. Schofield, K. Hassanali, M. Rodriguez Chaves, E. Johannesen, and Z. Sun at the WMU-Sasakawa Global Ocean Institute, S. Whelan (Observor Mission Holy See to the UN), as well as gender research and capacity-building programme support from Fisheries and Oceans Canada and The Nippon Foundation ofJapan.

170 G. Thunberg, Address to UN Climate Change Conference, Katowice, Poland, 15 December 2018: 'Unpopular', No one is too small to make a difference (London: Penguin, 2019) at 16.

171 See IISD, Summary of the Third Session of the IGC, 3rd Session of the Intergovernmental Conference (IGC) on the Conservation and Sustainable Use of Marine Biodiversity of Areas Beyond National Jurisdiction, 19-30 August 2019, available at: http://enb.iisd.org/ oceans/bbnj/igc3/.

172 R. Long, 'Enhancing the role of Women in Marine Scientific Research', International Workshop on Capacity Development, Resources and Needs Assessment, Kingston, Jamaica, 12 February 2020. 